\title{
The Increased Rate of Loss of Penicillinase Plasmids from Staphylococcus aureus in the Presence of Rifampicin
}

\author{
By J. H. JOHNSTON AND M. H. RICHMOND \\ Department of Bacteriology, University of Bristol, University Walk, \\ Bristol, BS \& ITD
}

\section{(Accepted for publication 9 October 1969)}

There have been a number of reports of the ability of various chemicals to increase the rate of loss of penicillinase and other plasmids from Staphylococcus aureus. Hashimoto, Kono \& Mitsuhashi (I964) reported that I7 out of I8 staphylococcal strains grown overnight in the presence of $25 \mu \mathrm{g}$. acriflavine $/ \mathrm{ml}$. showed an increased number of penicillinase-less variants, and Harmon \& Baldwin (I964) reported $6.2 \%$ penicillin-sensitive cocci in a staphylococcal culture grown overnight in Io $\mu \mathrm{g}$. acridine orange/ml. However Novick (I963) and Richmond (1965) were unable to show any curing of staphylococcal strains using acridine dyes, and consequently the effect of these compounds must be regarded as rather variable from strain to strain. Recently Bouanchaud, Scavizzi \& Chabbert (1969) have reported the elimination of pencillinase plasmids from certain staphylococcal strains with ethidium bromide, a drug known to intercalate between DNA base pairs, thus indirectly hindering the action of DNA and RNA polymerases (Waring, 1966).

The work presented here follows an observation that rifampicin (a rifamycin derivative-Maggi, Pasqualucci, Ballotta \& Sensi, I966) also has a curative effect on some staphylococcal extrachromosomal elements. This observation is of particular interest since the rifamycins bind directly to the RNA polymerase molecule itselfat least in Escherichia coli (Hartmann, Honikel, Knüsel \& Staehelin, 1967; Wehrli, Nüesch, Knüsel \& Staehelin, I968; Wehrli, Knüsel, Schmid \& Staehelin, 1968) and in Staphylococcus aureus (Wehrli, Knüsel \& Staehelin, 1968)-rather than acting indirectly by intercalation.

In a preliminary experiment it was found that a culture of penicillin-resistant staphylococci grown at $35^{\circ}$ in tryptone/soya broth containing $0 \cdot 0 \mathrm{I} \mu \mathrm{g}$. rifampicin $/ \mathrm{ml}$. contained about $20 \%$ of penicillinase-less variants after overnight growth while a culture incubated in the absence of the antibiotic contained $0.2 \%$ at most. This concentration of rifampicin was about two-thirds of the growth-inhibitory concentration for the strain used here under these growth conditions.

To investigate this phenomenon further, inocula of various sizes of Staphylococcus aureus strain 8325 ( $\alpha i^{-} p^{+}$cad-r ero-r)-that is, a staphylococcal culture containing a Com I plasmid conferring resistance to penicillin, cadmium ions and to erthyromycin (Richmond, 1969) -were made into batches of tryptone/soya broth each containing a different concentration of rifampicin and the cultures incubated at $35^{\circ}$ overnight. A similar culture, inoculated with $10^{5}$ organisms $/ \mathrm{ml}$. and incubated in the absence of rifampicin, acted as control. After overnight growth, samples from the cultures were plated onto nutrient agar to give single colonies, and after these colonies had grown 
they were replica-plated on to further nutrient agar plates containing either $10^{-4}$ M-cadmium acetate or Io $\mu \mathrm{g}$. erthythromycin $/ \mathrm{ml}$. to score for the presence of the plasmid $c a d-r$ and the ero-r markers respectively. After replication, the master plates were also stained to test for the presence of penicillinase-that is for the presence of the $i^{-} p^{+}$gene group. The results of this experiment are shown in the Table. The incidence of penicillinase-less cocci was greatest with an inoculum of $10^{5}$ organisms/ $\mathrm{ml}$. and a concentration of $0.0 \mathrm{I} \mu \mathrm{g}$. rifampicin $/ \mathrm{ml}$. and reached a value 100 times higher than the level found in the control. All the penicillinase-less colonies that were detected had also lost the cad-r and ero-r markers, indicating that the whole penicillinase plasmid ( $\alpha i^{-} p^{+}$cad-r ero-r), rather than the penicillinase genes alone, had been lost from the cocci.

Table I. The incidence of plasmid-less cocci in a culture of $S$. aureus $8325\left(\alpha i-p^{+}\right.$cad-r ero-r) incubated in tryptone/soya broth containing various concentrations of rifampicin

\begin{tabular}{|c|c|c|c|c|}
\hline \multirow[b]{2}{*}{$\begin{array}{l}\text { Inoculum size } \\
\text { (cocci/ml.) }\end{array}$} & \multirow[b]{2}{*}{$\begin{array}{c}\text { Rifampicin } \\
\text { concn } \\
(\mu \mathrm{g} . / \mathrm{ml} .)\end{array}$} & \multicolumn{3}{|c|}{ Incidence of plasmid-less cocci } \\
\hline & & $\begin{array}{l}\text { Total no. of } \\
\text { colonies tested }\end{array}$ & $\begin{array}{l}\text { No. of } \\
\text { plasmid-less } \\
\text { colonies }\end{array}$ & $\begin{array}{c}\text { No. of } \\
\text { plasmid-less } \\
\text { colonies (\%) }\end{array}$ \\
\hline $10^{4}$ & $\begin{array}{l}0.0075 \\
0.1 \\
0.025\end{array}$ & $\begin{array}{c}266 \\
\text { No growth } \\
\text { No growth }\end{array}$ & 66 & 25 \\
\hline $10^{5}$ & $\begin{array}{l}0.0075 \\
0.01 \\
0.025 \\
\text { Nil }\end{array}$ & $\begin{array}{r}\text { IOI I } \\
498 \\
861 \\
\text { I } 224\end{array}$ & $\begin{array}{r}163 \\
127 \\
19 \\
0\end{array}$ & $\begin{array}{c}16 \\
\quad 2 \cdot 2 \\
<0 \cdot I\end{array}$ \\
\hline $10^{6}$ & $\begin{array}{l}0.0075 \\
0.01\end{array}$ & $\begin{array}{l}863 \\
962\end{array}$ & $\begin{array}{r}69 \\
662\end{array}$ & 45 \\
\hline
\end{tabular}

One possible origin of the high proportion of plasmid-less variants in the treated culture was that rifampicin might select the plasmid-less variants known to occur spontaneously during the growth of this strain in liquid medium (Novick, 1963). To exclude this possibility, the rates of growth of the parent, a spontaneously occurring plasmid-less variant and a plasmid-less variant that had arisen previously in the presence of rifampicin were compared. In no case was there a detectable difference between the growth rates of the strains.

Similar experiments carried out with a Com II penicillinase plasmid, carried in this case in strain 147 (Richmond, 1969), have shown that a similar concentration of rifampicin to that used above produced $8.9 \%$ of plasmid-less cocci after overnight growth against $0.11 \%$ found in the control culture.

In view of the primary effect of rifampicin on RNA polymerase, the differential effect of rifampicin on bacterial growth and on plasmid survival suggests that there may be a specific RNA polymerase molecule or group of molecules involved in plasmid replication and plasmid distribution to daughter cells in Staphylococcus aureus.

We are very grateful to Professor H. Bein and Dr F. Knüsel of CIBA Ltd., Basle, for a gift of rifampicin; and to Abbott Laboratories Ltd. for a gift of erythromycin. This research was supported by a grant from the Medical Research Council. 


\section{REFERENCES}

Bouanchaud, D. H., SCAvizzi, M. R. \& ChabberT, Y. A. (1969). Elimination by ethidium bromide of antibiotic resistance in enterobacteria and staphylococci. Journal of General Microbiology 54,4 I7.

HARMON, S. \& BALDWIN, J. N. (1964). Nature of the determinant controlling penicillinase production in Staphylococcus aureus. Journal of Bacteriology 87, 593.

Hartmann, G., Honikel, K. O., Knüsel, F. \& Staehelin, M. (1967). The specific inhibition of the DNA directed RNA synthesis by rifampicin. Biochimica et Biophysica Acta 145, 843.

Hashimoto, M., Kono, K. \& Mitsuhashi, S. (1964). Elimination of penicillin resistance of Staphylococcus aureus by treatment with acriflavine. Journal of Bacteriology 88, $26 \mathrm{I}$.

Maggi, N., Pasqualucci, R., Ballotta, R. \& Sensi, P. (I966). Rifampicin: a new orally active rifamycin. Chemotherapia II, 285.

Novick, R. P. (1963). Analysis by transduction of mutations affecting penicillinase formation in Staphylococcus aureus. Journal of General Microbiology 33, I2I.

Richmond, M. H. (1965). Penicillinase plasmids in Staphylococcus aureus. British Medical Bulletin 2I, 260.

Richmond, M. H. (1969). The plasmids of Staphylococcus aureus and their relation to other extrachromosomal elements in bacteria. Advances in Microbial Physiology. Ed. by A. H. Rose and J. F. Wilkinson, vol 2, p. 43. London: Academic Press.

WARING, M. (1966). Cross-linking and intercalation in nucleic acids. Symposia of the Society for General Microbiology 16, 235.

Wehrli, W., KNüsel, F., Schmid, K. \& Staehelin, M. (I968). Interaction of rifampicin with bacterial RNA polymerase. Proceedings of the National Academy of Sciences of the United States of America 6r, 667.

WeHRLI, W., KNÜSEL, F. \& Staehelin, M. (1968). Action of rifamycin on RNA-polymerase from sensitive and resistant bacteria. Biochemical and Biophysical Research Communications 32, 284.

Wehrl, W., Nüesch, J., KNüsel, F. \& Staehelin, M. (1968). Interaction of rifamycin with bacterial RNA polymerase. Biochimica et Biophysica Acta 157, 215. 